\title{
Determination of Seasonal Variation of Air Pollution in Rize Province by Using a Type of Biomonitor Moss Hypnum
}

\author{
Nilay AKÇAY', Hasan BALTAŞ², Nevzat BATAN³ ${ }^{3}$ Güray UYAR ${ }^{4}$, Selami YANGIN5, Murat KARAYILAN6 ve \\ Kemal FERAH ${ }^{7}$ \\ 1Faculty of Art and Science, Recep Tayyip Erdogan University, Rize, Turkey \\ ${ }^{2}$ Faculty of Art and Science, Recep Tayyip Erdogan University, Rize, Turkey \\ ${ }^{3}$ Macka Vocational School, Karadeniz Technical University, Trabzon, Turkey \\ ${ }^{4}$ Polatlı Science \& Arts Faculty, Ankara Hacı Bayram Veli University, Ankara, Turkey \\ ${ }^{5}$ Faculty of Education, Recep Tayyip Erdogan University, Rize, Turkey \\ 6The Institute of Applied Science, Recep Tayyip Erdogan University, Rize, Turkey \\ ${ }^{7}$ The Institute of Applied Science, Recep Tayyip Erdogan University, Rize, Turkey
}

(Alınış / Received: 07.01.2019, Kabul / Accepted: 24.10.2019)

Keywords

Rize,

Moss,

Hypnum,

Pollution

EDXRF

\begin{abstract}
In this study, in order to determine the variation of seasonal air pollution levels in Rize province, Hypnum c. samples placed in the moss bags were placed into 12 stations during 4 seasons. Hypnum c. samples not placed in stations was defined as a control sample and was used to compare $\mathrm{Cr}, \mathrm{Fe}, \mathrm{Ni}, \mathrm{Cu}, \mathrm{Pb}$ and $\mathrm{Al}$ concentrations in the stations. $\mathrm{Cr}, \mathrm{Fe}, \mathrm{Ni}, \mathrm{Cu}, \mathrm{Pb}$ and $\mathrm{Al}$ concentrations of Hypnum c. samples, in control samples and the stations, were determined by using EDXRF Spectrometer. The average concentrations of $\mathrm{Cr}, \mathrm{Fe}, \mathrm{Ni}, \mathrm{Cu}, \mathrm{Pb}$ and $\mathrm{Al}$ in the stations were found as

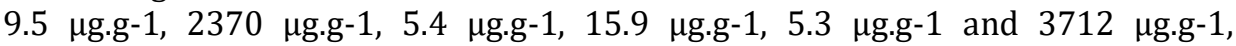
respectively. These values were compared with the results obtained from other studies for determining heavy metal levels in samples of mosses, in Turkey. It was found that the average $\mathrm{Al}$ value in this study was higher than the average Al value obtained from national studies and average $\mathrm{Cr}, \mathrm{Fe}, \mathrm{Ni}, \mathrm{Cu}$ and $\mathrm{Pb}$ values were lower than the average $\mathrm{Cr}, \mathrm{Fe}, \mathrm{Ni}, \mathrm{Cu}$ and $\mathrm{Pb}$ values obtained from national studies. In addition, the average metal values obtained from this study were compared with the permissible metal limits for plants. The average $\mathrm{Ni}, \mathrm{Cu}$ and $\mathrm{Pb}$ values were found lower than permissible values for plants and $\mathrm{Cr}$, $\mathrm{Fe}$ and $\mathrm{Al}$ values were found higher than the permissible values for plants. Kruskal Wallis $\mathrm{H}$ test was used to determine if there was a difference in terms of the amounts of $\mathrm{Cr}, \mathrm{Fe}, \mathrm{Ni}, \mathrm{Cu}, \mathrm{Pb}$ and $\mathrm{Al}$ between the control sample and stations and between stations and seasons. According to the test results, there was no statistically significant difference in terms of $\mathrm{Cr}, \mathrm{Fe}, \mathrm{Ni}, \mathrm{Cu}$, $\mathrm{Pb}$ and $\mathrm{Al}$ concentrations between control samples and stations. Even though the total amount of $\mathrm{Cr}, \mathrm{Ni}$ and $\mathrm{Cu}$ in the stations were seasonally different, these values did not make a statistically significant difference. According to the results of KWH test, total Fe amount in stations was found highest in Spring, lowest in Autumn, total $\mathrm{Al}$ amount was found highest in Spring, lowest in Summer, total $\mathrm{Pb}$ amount was found highest in Winter and lowest in Autumn and total $\mathrm{Fe}, \mathrm{Al}$ and $\mathrm{Pb}$ levels showed statistically significant difference in terms of seasons.
\end{abstract}

\section{Rize İlindeki Hava Kirliliğinin Mevsimsel Değişiminin Bir Biyomonitor Karayosunu Türü Olan Hypnum cupressiforme Kullanılarak Belirlenmesi}

\author{
Anahtar Kelimeler \\ Rize, \\ karayosunu, \\ Hypnum, \\ kirlilik, \\ EDXRF
}

Özet: Bu çalışmada, Rize ilindeki mevsimsel hava kirliliği seviyesinin değişimini belirlemek amacıyla, 4 mevsim boyunca 12 istasyona karayosunu çantalarına yerleştirilen Hypnum c. numuneleri konuldu. İstasyonlara yerleştirilmeyen Hypnum c. örnekleri kontrol numunesi olarak tanımlandı ve istasyonlardaki $\mathrm{Cr}, \mathrm{Fe}$, $\mathrm{Ni}, \mathrm{Cu}, \mathrm{Pb}$ ve Al konsantrasyonlarının karşılaştrılması için kullanıldı. Kontrol 
numunesi ve istasyonlardaki Hypnum c. örneklerindeki $\mathrm{Cr}, \mathrm{Fe}, \mathrm{Ni}, \mathrm{Cu}, \mathrm{Pb}$ ve $\mathrm{Al}$ konsantrasyonları EDXRF Spektrometresi kullanılarak tespit edildi. İstasyonlardaki

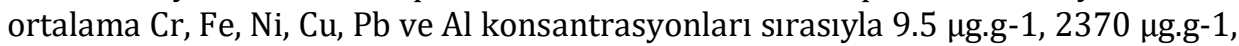

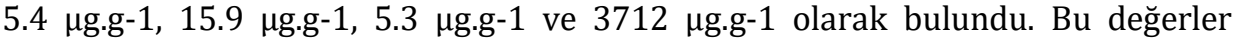
Türkiye'de karayosunu örneklerindeki metal seviyelerinin belirlenmesi için yapılan çalışmalardan elde edilen sonuçlarla kıyaslandı. Bu çalışmadaki ortalama $\mathrm{Al}$ değerinin ulusal çalışmalardan elde edilen ortalama Al değerinden yüksek olduğu ve ortalama $\mathrm{Cr}, \mathrm{Fe}, \mathrm{Ni}, \mathrm{Cu}$ ve $\mathrm{Pb}$ değerlerinin ulusal çalışmalardan elde edilen ortalama $\mathrm{Cr}, \mathrm{Fe}, \mathrm{Ni}, \mathrm{Cu}$ ve $\mathrm{Pb}$ değerlerinden düşük olduğu bulundu. Bu çalışmadan elde edilen ortalama metal değerleri, bitkiler için izin verilen metal limitleri ile karşılaştırıldı. Ortalama $\mathrm{Ni}, \mathrm{Cu}$ ve $\mathrm{Pb}$ değerleri bitkilerde izin verilen değerlerden düșük ve $\mathrm{Cr}$, Fe ve Al değerleri bitkilerde izin verilen değerlerden yüksek bulundu. Kontrol numunesi ve istasyonlar arasında ve istasyonlardaki numunelerin mevsimler arasında $\mathrm{Cr}, \mathrm{Fe}, \mathrm{Ni}, \mathrm{Cu}, \mathrm{Pb}$ ve $\mathrm{Al}$ miktarları bakımından farklılık gösterip göstermediğini belirlemek için Kruskal Wallis $\mathrm{H}$ testi kullanıldı. Test sonuçlarına göre kontrol numunesi ve istasyonlardaki $\mathrm{Cr}, \mathrm{Fe}, \mathrm{Ni}, \mathrm{Cu}, \mathrm{Pb}$ ve $\mathrm{Al}$ konsantrasyonları bakımından istatistiksel olarak anlamlı bir farka rastlanmadı. İstasyonlardaki toplam $\mathrm{Cr}$, Ni ve $\mathrm{Cu}$ miktarları mevsimsel olarak farklı değerlere sahip olsalar bile bu değerler istatistiksel olarak anlamlı bir fark oluşturmadı. KWH testi sonucuçlarına göre istasyonlardaki toplam Fe miktarı en yüksek İlkbahar, en düşük Sonbahar, toplam Al miktarı en yüksek İlkbahar en düşük Yaz, toplam Pb miktarı en yüksek Kış, en düşük Sonbahar mevsiminde bulundu ve toplam $\mathrm{Fe}$, $\mathrm{Al}$ ve $\mathrm{Pb}$ miktarları mevsimler açısından istatistiki olarak anlamlı bir farklılaşma gösterdiği tespit edildi.

\section{Introduction}

Air pollution is an important environmental problem that concerns countries, cities and all settlement areas. Air pollutants can be spread to the air from fertilizers used in agricultural activities, wastes in industrial and production facilities, exhaust fumes in traffic, fossil fuels used in heating and through transport of chemicals in garbages by winds.

One of the most important pollutants in the air is heavy metals. Heavy metals consist of metals such as chromium (Cr), iron (Fe), nickel (Ni), copper (Cu), lead $(\mathrm{Pb})$ and aluminum $(\mathrm{Al})$. While some of these metals are necessary for human, animal and plant health, some of these may cause harmful effects when they exceed limit values.

In recent years, intensive attention has been paid to the problems of heavy metal pollution in the air of settlement areas. Various electronic devices have been developed to measure the amount of heavy metals in the air. Besides, biomonitor organisms such as mosses are used in biomonitoring studies because they can accumulate heavy metals and allow for seasonal measurements.

The mosses don't contain xylem and phloem tissues and accumulate water and dissolved organic matter directly in their body. For this reason, mosses are used as biomonitor organisms in environments where they develop naturally or in transplants $[1,2,3,4]$. In particular, in cities where the mosses are rare or not present, the moss bag technique was developed to measure air pollution [5].
Nylon mesh filters are generally used in the moss bag technique. The mosses are placed in the filters and hung on the stations where heavy metal pollution is desired to be measured.

The aim of this study is to determine seasonal variation of air pollution in Rize Province by using a type of biomonitor moss Hypnum cupressiforme.

\section{Materials and Method}

In this study, plenty of Hypnum cupressiforme samples were collected around Kaçkar Mountains National Parks where the population, traffic and industrialization are few. The collected Hypnum cupressiforme samples were brought to the laboratory, placed on a plastic covers, divided into equal units, cleaned of polluting materials such as sand, dust and soil. 2 grams of samples were taken from each unit and approximately 70 samples of 140 grams were prepared. Some of these samples were separated as control samples to compare the pollution of moss bags placed to the stations. The other samples were placed in the plastic boxes (moss bags) with a diameter of $15 \mathrm{~cm}$ and a depth of $8 \mathrm{~cm}$ with the help of nylon nets spaced $1 \mathrm{~cm}$ apart.

Prepared moss bags were placed to the stations showed in Table 1 and Figure 1, between 2015 and 2016 years, for three months and for four seasons. Station numbers S1, S2, S3, S4, S5, S6, S7, S8, S9, S10, S11 and S12 were belongs to Hopa-Sarp Black Sea Coastal Road Crossroad-1, Crossroad-2, Crossroad-3, Crossroad-4, Crossroad-5, Tevfik İleri Street-1, Tevfik 
İleri Street-2, Meydan Street, Sendika Street, Adliye Street-1, Adliye Street-2, Atmeydani Street Dosma Vocational School of Technical Sciences which were in Rize city, respectively. The metal levels of the Hypnum cupressiforme samples which not placed in any stations, and separated as control samples were defined as the control value (Scontrol) and used to compare the pollution levels of moss in the moss bags at the stations.

S1, S2, S3, S4 and S5 were the stations on the HopaSarp Black Sea Coastal Road Crossroad that passes through the Central district of Rize. The purpose of choosing these stations is that this crossroad is the crossing point of the vehicles coming from east, west and south to Rize province. In addition, this crossroad is on the transit route of buses and minibuses, where people living in the city use their cars a lot.

S6, S7 and S8 stations were close to shopping centers and markets. The purpose of selecting these stations is to compare whether there is a difference about air pollution between these stations where people perform some of their shopping and the stations where traffic is more intense.

S9, S10 and S11 stations were close to Rize city square, a primary school, a high school and a library. The purpose of selecting these stations is to determine whether vehicles and buildings passing around the square contribute to pollution at these stations.

The S12 station was located a few km from Rize city center. The S12 station was close to a primary school and one of the Vocational School where the Recep Tayyip Erdogan University has the highest number of students. The purpose of selecting this station is to compare the pollution caused by traffic and buildings around these schools with other stations.

In Table 1, the codes started with $1 \mathrm{~S}, 2 \mathrm{~S}, 3 \mathrm{~S}$ and $4 \mathrm{~S}$ were defined as the stations for the samples in summer, autumn, winter and spring, respectively.

Table 1. Information about stations

\begin{tabular}{|c|c|c|c|c|}
\hline \multicolumn{4}{|c|}{ Stations } & \multirow[b]{2}{*}{ Coordinates } \\
\hline $1 \mathrm{~S}$ & $2 \mathrm{~S}$ & $3 \mathrm{~S}$ & $4 \mathrm{~S}$ & \\
\hline $1 \mathrm{~S} 1$ & $2 \mathrm{~S} 1$ & $3 \mathrm{~S} 1$ & $4 \mathrm{~S} 1$ & $41^{\circ} 01^{\prime} 33.9^{\prime \prime} \mathrm{N} ; 40^{\circ} 31^{\prime} 14.7^{\prime \prime E}$ \\
\hline $1 \mathrm{~S} 2$ & $2 \mathrm{~S} 2$ & $3 \mathrm{~S} 2$ & $4 \mathrm{~S} 2$ & $41^{\circ} 01^{\prime} 36.2^{\prime \prime} \mathrm{N} ; 40^{\circ} 31^{\prime} 15.7^{\prime \prime} \mathrm{E}$ \\
\hline $1 \mathrm{S3}$ & $2 \mathrm{~S} 3$ & $3 \mathrm{~S} 3$ & $4 \mathrm{~S} 3$ & $41^{\circ} 01^{\prime} 38.0^{\prime \prime} \mathrm{N} ; 40^{\circ} 31^{\prime} 14.1^{\prime \prime} \mathrm{E}$ \\
\hline 154 & $2 \mathrm{~S} 4$ & $3 \mathrm{~S} 4$ & $4 \mathrm{~S} 4$ & $41^{\circ} 01^{\prime} 37.7^{\prime \prime} \mathrm{N} ; 40^{\circ} 31^{\prime} 07.8^{\prime \prime} \mathrm{E}$ \\
\hline $1 \mathrm{~S} 5$ & $2 \mathrm{~S} 5$ & $3 \mathrm{~S} 5$ & $4 \mathrm{~S} 5$ & $41^{\circ} 01^{\prime} 34.5^{\prime \prime} \mathrm{N} ; 40^{\circ} 31^{\prime} 08.9^{\prime \prime} \mathrm{E}$ \\
\hline 156 & $2 \mathrm{~S} 6$ & $3 \mathrm{~S} 6$ & $4 \mathrm{~S} 6$ & $41^{\circ} 01^{\prime} 30.2^{\prime \prime} \mathrm{N} ; 40^{\circ} 31^{\prime} 12.0^{\prime \prime} \mathrm{E}$ \\
\hline $1 \mathrm{S7}$ & $2 \mathrm{~S} 7$ & $3 \mathrm{~S} 7$ & $4 \mathrm{~S} 7$ & $41^{\circ} 01^{\prime} 28.2^{\prime \prime} \mathrm{N} ; 40^{\circ} 31^{\prime} 11.1^{\prime \prime} \mathrm{E}$ \\
\hline 158 & $2 \mathrm{~S} 8$ & $3 \mathrm{~S} 8$ & $4 \mathrm{~S} 8$ & $41^{\circ} 01^{\prime} 27.2^{\prime \prime} \mathrm{N} ; 40^{\circ} 31^{\prime} 10.3^{\prime \prime} \mathrm{E}$ \\
\hline 159 & $2 \mathrm{~S} 9$ & $3 \mathrm{~S} 9$ & $4 \mathrm{~S} 9$ & $41^{\circ} 01^{\prime} 35.5^{\prime \prime} \mathrm{N} ; 40^{\circ} 30^{\prime} 57.5^{\prime \prime} \mathrm{E}$ \\
\hline $1 \mathrm{~S} 10$ & $2 \mathrm{~S} 10$ & $3 \mathrm{~S} 10$ & $4 \mathrm{~S} 10$ & $41^{\circ} 01^{\prime} 34.5^{\prime \prime} \mathrm{N} ; 40^{\circ} 30^{\prime} 56.1^{\prime \prime} \mathrm{E}$ \\
\hline $1 \mathrm{~S} 11$ & $2 \mathrm{~S} 11$ & $3 \mathrm{~S} 11$ & $4 \mathrm{~S} 11$ & $41^{\circ} 01^{\prime} 34.5 " \mathrm{~N} ; 40^{\circ} 30^{\prime} 56.7^{\prime \prime E}$ \\
\hline $1 \mathrm{~S} 12$ & $2 \mathrm{~S} 12$ & $3 \mathrm{~S} 12$ & $4 \mathrm{~S} 12$ & $41^{\circ} 00^{\prime} 58.8^{\prime \prime} \mathrm{N} ; 40^{\circ} 30^{\prime} 38.8^{\prime \prime} \mathrm{E}$ \\
\hline Scont & Scont & Scont & Scont & $40^{\circ} 57^{\prime} 32.6^{\prime \prime N} ; 40^{\circ} 57^{\prime} 46.6^{\prime \prime E}$ \\
\hline
\end{tabular}

1S:Summer, 2S: Autumn, 3S: Winter, 4S: Spring

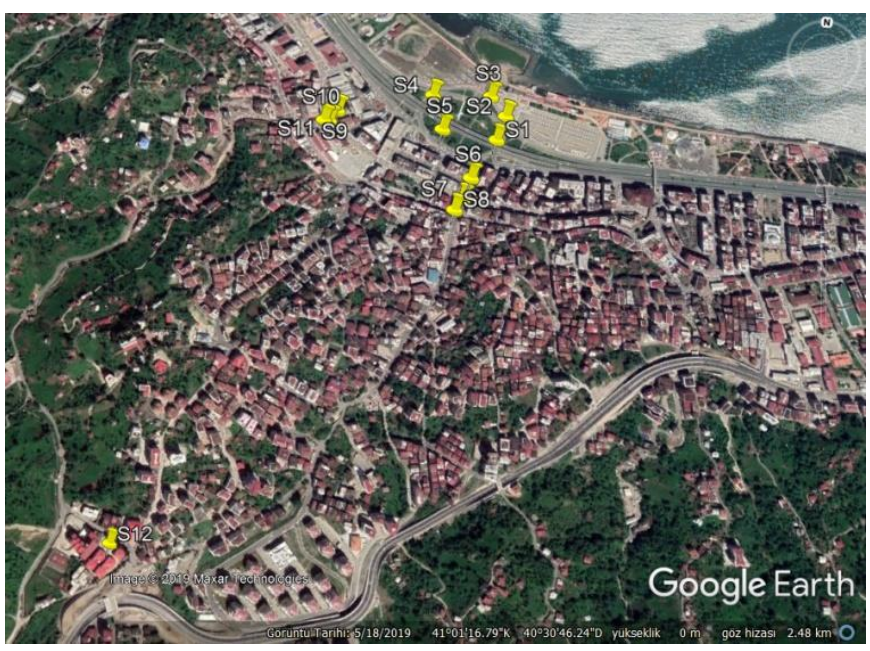

Figure 1. Study area and the stations

Moss bags, which were kept for three months, were taken from the stations and brought to the laboratory. They were cleaned from polluting materials and dried in an oven at $1050 \mathrm{c}$ for 24 hours. Branches of dried samples were picked up, weighed 10 grams, placed in the grinding mill and pulverized. $2 \mathrm{~g}$ of the powdered samples were mixed with $0.5 \mathrm{~g}$ of boric acid. In order to analyze heavy metals of the moss samples on the EDXRF spectrometer (Epsilon 5, PANanalytical), pressure was applied on the hydraulic press machine for $20 \mathrm{~s}$ to pellets.

The IAEA-336 Lichen reference material [6] was used to verify the measurement results of the EDXRF instrument. The data for the reference material were shown in Table 2.

Table 2. Measured and reference values of IAEA336( $\mu g g-1)$

\begin{tabular}{|l|l|l|}
\hline Metals & Measured value & Reference value \\
\hline $\mathrm{Cr}$ & 1.1 & $0.89-1.23$ \\
\hline $\mathrm{Fe}$ & 415.8 & $380-480$ \\
\hline $\mathrm{Ni}$ & - & - \\
\hline $\mathrm{Pb}$ & 4.8 & $4.3-5.5$ \\
\hline $\mathrm{Al}$ & 597.3 & $570-790$ \\
\hline
\end{tabular}

\section{Results}

The results of the heavy metal levels ( $\mathrm{Cr}, \mathrm{Fe}, \mathrm{Ni}, \mathrm{Cu}, \mathrm{Pb}$ and $\mathrm{Al}$ ) in the moss bags for 4 seasons were shown in Table 3-6. Table 7 shows the minimum, maximum and average heavy metal concentrations in all samples in the stations and the control sample.

In Table 3 , the highest $\mathrm{Cr}, \mathrm{Ni}, \mathrm{Cu}, \mathrm{Fe}, \mathrm{Pb}$ and $\mathrm{Al}$ concentrations in first season (summer) samples were found as $37.6 \mu \mathrm{g} . \mathrm{g}-1,14.1 \mu \mathrm{g} . \mathrm{g}-1,49.4 \mu \mathrm{g} . \mathrm{g}-1$ (1S11), $3100 \mu \mathrm{g} . \mathrm{g}-1$ (1S7), $9.8 \mu \mathrm{g} . \mathrm{g}-1$ (1S10) and $5325 \mu \mathrm{g} . \mathrm{g}-1$ (1S4). In the same samples, the average $\mathrm{Cr}, \mathrm{Fe}, \mathrm{Ni}, \mathrm{Cu}$, $\mathrm{Pb}$ and $\mathrm{Al}$ concentrations were determined as 12.4

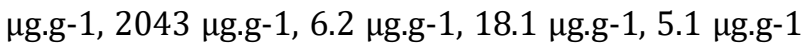
and $2870 \mu \mathrm{g} . \mathrm{g}-1$, respectively. 
Table 3. Heavy metal concentrations in first season samples ( $\mu$ g.g-1)

\begin{tabular}{|l|l|l|l|l|l|l|}
\hline & $\mathrm{Cr}$ & $\mathrm{Fe}$ & $\mathrm{Ni}$ & $\mathrm{Cu}$ & $\mathrm{Pb}$ & $\mathrm{Al}$ \\
\hline 1S1 & 8.3 & 967 & 3.5 & 7.4 & 4.2 & 1366 \\
\hline 1S2 & 7.4 & 2213 & 5.8 & 15.4 & 4.5 & 2297 \\
\hline 1S3 & 7.4 & 1961 & 5.1 & 15.1 & 5.5 & 2348 \\
\hline 1S4 & 5.2 & 1152 & 2.6 & 10.6 & 2.2 & 5325 \\
\hline 1S5 & 29.6 & 2321 & 10.4 & 33.3 & 6.0 & 4260 \\
\hline 1S6 & 8.5 & 2018 & 5.2 & 17.7 & 4.6 & 1943 \\
\hline 1S7 & 9.1 & 3100 & 4.9 & 16.4 & 4.6 & 3371 \\
\hline 1S8 & 7.6 & 2808 & 5.2 & 14.1 & 4.0 & 3592 \\
\hline 1S9 & 11.5 & 1940 & 6.8 & 13.8 & 4.6 & 1920 \\
\hline 1S10 & 7.0 & 2106 & 5.2 & 13.8 & 9.8 & 2875 \\
\hline 1S11 & 37.6 & 1852 & 14.1 & 49.4 & 6.8 & 2634 \\
\hline 1S12 & 9.1 & 2088 & 6.0 & 10.1 & 4.1 & 2511 \\
\hline Scont & 8.4 & 2185 & 5.8 & 14.8 & 5.4 & 3234 \\
\hline
\end{tabular}

In Table 4, the highest $\mathrm{Cr}, \mathrm{Ni}, \mathrm{Cu}, \mathrm{Pb}, \mathrm{Fe}$ and $\mathrm{Al}$ concentrations in second season (autumn) samples were found as $11.6 \mu \mathrm{g} . \mathrm{g}-1,6.8 \mu \mathrm{g} . \mathrm{g}-1$ (2S7), $20.0 \mu \mathrm{g} . \mathrm{g}-$ 1, $5.2 \mu \mathrm{g} . \mathrm{g}-1$ (2S76), $2562 \mu \mathrm{g} . \mathrm{g}-1$ (2S2) and $3568 \mu \mathrm{g} . \mathrm{g}-$ 1 (2S1). In the same samples, the average $\mathrm{Cr}, \mathrm{Fe}, \mathrm{Ni}, \mathrm{Cu}$, $\mathrm{Pb}$ and Al concentrations were determined as $7.7 \mu \mathrm{g} . \mathrm{g}-$ 1, $1975 \mu \mathrm{g} . \mathrm{g}-1,4.9 \mu \mathrm{g} . \mathrm{g}-1,15.4 \mu \mathrm{g} . \mathrm{g}-1,4.3 \mu \mathrm{g} . \mathrm{g}-1$ and $2826 \mu$ g.g-1, respectively. Metal levels at stations 2S9 and 2S10 could not be detected. In Table 5, the highest $\mathrm{Fe}, \mathrm{Cu}, \mathrm{Pb}, \mathrm{Cr}, \mathrm{Ni}$ and $\mathrm{Al}$ concentrations in third season (winter) samples were found as $3592 \mu \mathrm{g} . \mathrm{g}-1,22.4 \mu \mathrm{g} . \mathrm{g}-1,8.5 \mu \mathrm{g} . \mathrm{g}-1$ (3S1), $14.8 \mu$ g.g-1 (3S10), $6.7 \mu g . g-1$ (3S9, 3S10) and 7156 $\mu \mathrm{g} . \mathrm{g}-1$ (3S5). In the same samples, the average $\mathrm{Cr}, \mathrm{Fe}$, $\mathrm{Ni}, \mathrm{Cu}, \mathrm{Pb}$ and $\mathrm{Al}$ concentrations were determined as $9.8 \mu \mathrm{g} . \mathrm{g}-1,2582 \mu \mathrm{g} . \mathrm{g}-1,5.1 \mu \mathrm{g} . \mathrm{g}-1,15.5 \mu \mathrm{g} . \mathrm{g}-1,6.6 \mu \mathrm{g} . \mathrm{g}-$ 1 and $4304 \mu \mathrm{g} . \mathrm{g}-1$. Metal levels at stations 3S8 could not be detected.

Table 4. Heavy metal concentrations in second season samples ( $\mu$ g.g-1)

\begin{tabular}{|l|l|l|l|l|l|l|}
\hline & $\mathrm{Cr}$ & $\mathrm{Fe}$ & $\mathrm{Ni}$ & $\mathrm{Cu}$ & $\mathrm{Pb}$ & $\mathrm{Al}$ \\
\hline 2S1 & 6.6 & 1731 & 4.2 & 17.9 & 3.6 & 3568 \\
\hline 2S2 & 6.0 & 2562 & 5.5 & 12.9 & 4.9 & 2800 \\
\hline 2S3 & 6.4 & 1911 & 4.5 & 13.8 & 4.3 & 2871 \\
\hline 2S4 & 6.6 & 2094 & 4.4 & 15.6 & 4.0 & 3266 \\
\hline 2S5 & 4.4 & 1146 & 2.2 & 13.1 & 2.7 & 2700 \\
\hline 2S6 & 10.2 & 2506 & 6.3 & 20.0 & 5.2 & 3013 \\
\hline 2S7 & 11.6 & 2299 & 6.8 & 15.3 & 4.5 & 2972 \\
\hline 2S8 & 9.3 & 1888 & 5.2 & 15.3 & 4.4 & 2143 \\
\hline 2S9 & nd & nd & nd & nd & nd & nd \\
\hline 2S10 & nd & nd & nd & nd & nd & nd \\
\hline 2S11 & 7.2 & 1618 & 5.1 & 18.0 & 4.9 & 1700 \\
\hline 2S12 & 8.8 & 2003 & 5.2 & 12.1 & 4.5 & 3227 \\
\hline Scont & 8.4 & 2185 & 5.8 & 14.8 & 5.4 & 3234 \\
\hline
\end{tabular}

Table 5. Heavy metal concentrations in third season samples ( $\mu$ g.g-1)

\begin{tabular}{|l|l|l|l|l|l|l|}
\hline & $\mathrm{Cr}$ & $\mathrm{Fe}$ & $\mathrm{Ni}$ & $\mathrm{Cu}$ & $\mathrm{Pb}$ & $\mathrm{Al}$ \\
\hline 3S1 & 12.4 & 3592 & 5.2 & 22.4 & 8.5 & 6344 \\
\hline 3S2 & 10.5 & 2656 & 5.4 & 17.7 & 8.4 & 4586 \\
\hline 3S3 & 8.1 & 2227 & 5.0 & 14.4 & 7.4 & 3840 \\
\hline 3S4 & 10.5 & 2877 & 6.1 & 21.0 & 8.0 & 4695 \\
\hline
\end{tabular}

\begin{tabular}{|l|l|l|l|l|l|l|}
\hline 3S5 & 8.4 & 3224 & 3.7 & 16.5 & 6.2 & 7156 \\
\hline 3S6 & 6.6 & 1398 & 3.7 & 12.8 & 2.7 & 1492 \\
\hline 3S7 & 6.6 & 1554 & 4.3 & 10.2 & 8.2 & 2024 \\
\hline 3S8 & nd & nd & nd & nd & nd & nd \\
\hline 3S9 & 12.8 & 2987 & 6.7 & 12 & 6.2 & 5660 \\
\hline 3S10 & 14.8 & 3014 & 6.7 & 17 & 5.3 & 4694 \\
\hline 3S11 & 8.6 & 2563 & 5.1 & 16 & 6.2 & 3380 \\
\hline 3S12 & 9.0 & 2312 & 4.2 & 11 & 5.1 & 3480 \\
\hline Scont & 8.4 & 2185 & 5.8 & 14.8 & 5.4 & 3234 \\
\hline
\end{tabular}

In Table 5, the highest $\mathrm{Fe}, \mathrm{Cu}, \mathrm{Pb}, \mathrm{Cr}, \mathrm{Ni}$ and $\mathrm{Al}$ concentrations in third season (winter) samples were found as $3592 \mu \mathrm{g} . \mathrm{g}-1,22.4 \mu \mathrm{g} . \mathrm{g}-1,8.5 \mu \mathrm{g} . \mathrm{g}-1$ (3S1), $14.8 \mu \mathrm{g} . \mathrm{g}-1$ (3S10), $6.7 \mu \mathrm{g} . \mathrm{g}-1$ (3S9, 3S10) and 7156 $\mu$ g.g-1 (3S5). In the same samples, the average $\mathrm{Cr}, \mathrm{Fe}$, $\mathrm{Ni}, \mathrm{Cu}, \mathrm{Pb}$ and $\mathrm{Al}$ concentrations were determined as $9.8 \mu \mathrm{g} . \mathrm{g}-1,2582 \mu \mathrm{g} . \mathrm{g}-1,5.1 \mu \mathrm{g} . \mathrm{g}-1,15.5 \mu \mathrm{g} . \mathrm{g}-1,6.6 \mu \mathrm{g} . \mathrm{g}-$ 1 and $4304 \mu \mathrm{g} . \mathrm{g}-1$. Metal levels at stations 3S8 could not be detected.

Table 6. Heavy metal concentrations in fourth season samples ( $\mu$ g.g-1)

\begin{tabular}{|l|l|l|l|l|l|l|}
\hline & $\mathrm{Cr}$ & $\mathrm{Fe}$ & $\mathrm{Ni}$ & $\mathrm{Cu}$ & $\mathrm{Pb}$ & $\mathrm{Al}$ \\
\hline 4S1 & 8.4 & 2932 & 5.6 & 18.8 & 5.2 & 4080 \\
\hline 4S2 & 6.7 & 2453 & 10.7 & 14.1 & 5.4 & 3765 \\
\hline 4S3 & 6.4 & 3168 & 3.6 & 17.6 & 4.6 & 5932 \\
\hline 4S4 & 7.8 & 3172 & 4.9 & 18.4 & 5.5 & 5185 \\
\hline 4S5 & 5.7 & 3781 & 7.2 & 24.0 & 10.2 & 6077 \\
\hline 4S6 & 5.9 & 3240 & 3.6 & 13.8 & 5.6 & 5420 \\
\hline 4S7 & 8.4 & 3338 & 4.1 & 9.6 & 2.7 & 5564 \\
\hline 4S8 & 10.5 & 2276 & 4.9 & 15.9 & 6.9 & 4576 \\
\hline 4S9 & 7.8 & 1535 & 4.3 & 9.2 & 3.8 & 2775 \\
\hline 4S10 & 6.5 & 2709 & 3.6 & 9.6 & 4.6 & 4319 \\
\hline 4S11 & 7.0 & 2210 & 5.2 & 12.1 & 4.8 & 3846 \\
\hline 4S12 & 16 & 3784 & 7.6 & 11.9 & 5.5 & 6671 \\
\hline Scont & 8.4 & 2185 & 5.8 & 14.8 & 5.4 & 3234 \\
\hline
\end{tabular}

In Table 6, the highest $\mathrm{Cr}, \mathrm{Fe}, \mathrm{Al}, \mathrm{Cu}, \mathrm{Pb}$ and $\mathrm{Ni}$ concentrations in fourth season (spring) samples were found as $16.0 \mu \mathrm{g} . \mathrm{g}-1,3784 \mu \mathrm{g} . \mathrm{g}-1,6671 \mu \mathrm{g} . \mathrm{g}-1$ (4S12), $24.0 \mu \mathrm{g} . \mathrm{g}-1,10.2 \mu \mathrm{g} . \mathrm{g}-1$ (4S5) and $10.7 \mu \mathrm{g} . \mathrm{g}-1$ (4S2). In the same samples, the average $\mathrm{Cr}, \mathrm{Fe}, \mathrm{Ni}, \mathrm{Cu}$, $\mathrm{Pb}$ and $\mathrm{Al}$ concentrations were determined as $8.1 \mu \mathrm{g} . \mathrm{g}-$ 1, $2883 \mu \mathrm{g} . \mathrm{g}-1,5.4 \mu \mathrm{g} . \mathrm{g}-1,14.6 \mu \mathrm{g} . \mathrm{g}-1,5.4 \mu \mathrm{g} . \mathrm{g}-1$ and $4850 \mu \mathrm{g} . \mathrm{g}-1$, respectively.

Table 7. Minimum, maximum and average heavy metal concentrations in all samples ( $\mu$ g.g-1)

\begin{tabular}{|l|l|l|l|l|l|l|}
\hline & $\mathrm{Cr}$ & $\mathrm{Fe}$ & $\mathrm{Ni}$ & $\mathrm{Cu}$ & $\mathrm{Pb}$ & $\mathrm{Al}$ \\
\hline $\min$ & 4.4 & 967 & 2.2 & 7.4 & 2.2 & 1366 \\
\hline max & 37.6 & 3784 & 14.1 & 49.4 & 10.2 & 7156 \\
\hline average & 9.5 & 2370 & 5.4 & 15.9 & 5.3 & 3712 \\
\hline Scont & 8.4 & 2185 & 5.8 & 14.8 & 5.4 & 3234 \\
\hline
\end{tabular}

\section{Discussion}

In this study that aims to determine the seasonal variation of air pollution in Rize province by using Hypnum cupressiforme which is a type of biomonitor moss, moss bags were placed to the 12 stations in the city center of Rize for 3 months during 4 seasons and 
heavy metal levels were determined. The average values obtained from this study were compared with the heavy metal levels of control sample and the heavy metal levels of the other studies about heavy metal levels detected in moss samples in Turkey showed in Table 8.

Table 8. Studies about heavy metal levels in moss samples in Turkey ( $\mu$ g.g-1)

\begin{tabular}{|l|l|l|l|l|l|l|}
\hline & $\mathrm{Cr}$ & $\mathrm{Fe}$ & $\mathrm{Ni}$ & $\mathrm{Cu}$ & $\mathrm{Pb}$ & $\mathrm{Al}$ \\
\hline Çatalagzi [7] & 4.81 & 2530 & 6.6 & 3.3 & $\begin{array}{l}21 . \\
1\end{array}$ & - \\
\hline Düzce [8] & 2.67 & 2003 & 2.1 & 9.2 & $\begin{array}{l}27 . \\
6\end{array}$ & - \\
\hline Eregli [9] & 5.1 & 3360 & 5.0 & 3.8 & $\begin{array}{l}24 . \\
4\end{array}$ & - \\
\hline İstanbul [10] & 14.6 & 5.93 & 12.1 & 24.8 & $\begin{array}{l}50 . \\
1\end{array}$ & 14.6 \\
\hline Blacksea [11] & 60.6 & - & 18.8 & 293 & $\begin{array}{l}39 . \\
8\end{array}$ & - \\
\hline Sakarya [12] & 9.7 & 2917 & 10.9 & 25.4 & $\begin{array}{l}14 . \\
7\end{array}$ & $\begin{array}{l}419 \\
4\end{array}$ \\
\hline Trakya [13] & 21.7 & 6000 & - & - & - & - \\
\hline Zonguldak [14] & 4.3 & 3771 & 6.6 & 13.6 & $\begin{array}{l}15 . \\
3\end{array}$ & - \\
\hline İstanbul [15] & 11.2 & 3100 & 8.0 & 27.2 & - & - \\
\hline average & 14.9 & 2960 & 8.7 & 50.0 & $\begin{array}{l}27 . \\
5\end{array}$ & $\begin{array}{l}210 \\
4\end{array}$ \\
\hline Present study & 9.5 & 2370 & 5.4 & 15.9 & 5.3 & $\begin{array}{l}371 \\
2\end{array}$ \\
\hline
\end{tabular}

When taking into account Table 7 and Table $8 \mathrm{Cr}$ concentration was found as $8.4 \mu \mathrm{g} . \mathrm{g}-1$ in the control sample and the average $\mathrm{Cr}$ concentration in the stations was detected as $9.5 \mu \mathrm{g} . \mathrm{g}-1$. This average $\mathrm{Cr}$ value in this study was above the recommended $\mathrm{Cr}$ concentration (2 $\mu \mathrm{g} . \mathrm{g}-1)$ for the plants [16] and was below the average $\mathrm{Cr}$ concentration value obtained from other studies in Turkey $(14.9 \mu \mathrm{g} . \mathrm{g}-1)$.

The Fe concentration was found as $2185 \mu \mathrm{g}$.g- 1 in the control sample. The average Fe concentration in the stations was detected as $2370 \mu \mathrm{g}$.g- 1 . The average Fe level in this study was found above the recommended limit $(200 \mu \mathrm{g} . \mathrm{g}-1)$ for the plants $[17,18]$ and was below the average $\mathrm{Fe}$ concentration value obtained from studies in Turkey (2960 $\mu$ g.g-1).

The recommended amount of $\mathrm{Ni}$ for plants is given as $10 \mu$ g.g-1 [19,20]. In this study, the average Ni value was found as $5.4 \mu \mathrm{g} . \mathrm{g}-1$ in stations and $5.8 \mu \mathrm{g} . \mathrm{g}-1$ in control sample. These values are both below the recommended $\mathrm{Ni}$ concentration for the plants and the average Ni concentration is obtained from Turkey (8.7 $\mu \mathrm{g} \cdot \mathrm{g}-1)$.

In this study, $\mathrm{Cu}$ concentration was found in the range of 7.4-49.4 $\mu \mathrm{g} . \mathrm{g}-1$ in stations, and $4.8 \mu \mathrm{g} . \mathrm{g}-1$ was detected in the control sample. While recommended $\mathrm{Cu}$ value in plants is given as $30 \mu \mathrm{g} . \mathrm{g}-1[19,20]$, in this study, the average $\mathrm{Cu}$ value was obtained as $15.9 \mu \mathrm{g} . \mathrm{g}-$ 1. This value is both below the recommended $\mathrm{Cu}$ concentration for the plants and the average $\mathrm{Cu}$ concentration of studies in Table 8 (50 $\mu \mathrm{g}$.g-1).
In this study, $\mathrm{Pb}$ concentration was found as $5.4 \mu \mathrm{g} . \mathrm{g}$ 1 in the control sample and the highest $\mathrm{Pb}$ concentration in the stations was detected as 10.2 $\mu \mathrm{g} . \mathrm{g}-1$. The permissible limit of $\mathrm{Pb}$ in plants is given as $10 \mu \mathrm{g} . \mathrm{g}-1$ [16,21]. In this study, the average $\mathrm{Pb}$ value was found as $5.3 \mu \mathrm{g} . \mathrm{g}-1$. This value is both below the recommended concentration for the plants and the average $\mathrm{Pb}$ concentration in Table 8 (27.5 $\mu$ g.g-1).

In this study, $\mathrm{Al}$ value was obtained as $3284 \mu \mathrm{g} . \mathrm{g}-1$ in control sample and average $\mathrm{Al}$ value found as 3715 $\mu g . g-1$ in stations. This values is higher than the permissible level for $\mathrm{Al}$ in plants (160 $\mu$ g.g-1) [22,23]. In addition, $\mathrm{Al}$ value in present study is above than the average value of the $\mathrm{Al}$ concentration obtained from the study about moss in Turkey (2104 $\mu$ g.g-1).

Kruskal Wallis $\mathrm{H}$ test was performed to determine whether there was a significant difference about $\mathrm{Cr}$, $\mathrm{Fe}, \mathrm{Ni}, \mathrm{Cu}, \mathrm{Pb}$ and $\mathrm{Al}$ metals in the stations according to the control sample and performed to determine whether the total $\mathrm{Cr}, \mathrm{Fe}, \mathrm{Ni}, \mathrm{Cu}, \mathrm{Pb}$ and $\mathrm{Al}$ concentrations in the stations had a significant difference in terms of four seasons. The data obtained from the results of the Kruskal Wallis $H$ tests were shown in Table 9 and Table 10. In Table 9; S1, S2, S3, S4, S5 stations are the first group, S6, S7, S8 stations are the second group, S9, S10, S11 stations are the third group, S12 station is the fourth group and Scontrol was defined as the fifth group.

When Table 9 is examined, according to Kruskal Wallis $\mathrm{H}$ test results, in the stations $\mathrm{Cr}$ amount is the highest in 3rd group ( $\mathrm{X}=34.38$ ) and the lowest in 5 th group $(X=18.48), F e$ amount is the highest in 4th group $(X=25.25)$ and the lowest in 5 th group $(X=19.00), \mathrm{Ni}$ amount is the highest in 3rd group ( $X=33.50)$ and the lowest in 2nd group ( $\mathrm{X}=20.32), \mathrm{Cu}$ amount is the highest in 3rd group ( $X=28.38)$ and the lowest in 4 th group ( $\mathrm{X}=8.38), \mathrm{Pb}$ amount is the highest in 3rd group $(X=28.50)$ and the lowest in 4th group $(X=19.25)$ and $\mathrm{Al}$ amount is the highest in 1st group $(X=27.05)$ and the lowest in 5 th group ( $X=19.55)$. The difference of $\mathrm{Cr}, \mathrm{Fe}, \mathrm{Ni}, \mathrm{Cu}, \mathrm{Pb}$ and $\mathrm{Al}$ levels between the control sample and other groups do not have a statistically significant difference ( $p>.05)$.

In Table 10, according to Kruskal Wallis $\mathrm{H}$ test results, in the spring season, the total $\mathrm{Cr}, \mathrm{Ni}$ and $\mathrm{Cu}$ levels of the stations are at the lowest level $(X=18.25,21.29$, 20.71) and the total $\mathrm{Cr}, \mathrm{Ni}$ and $\mathrm{Cu}$ levels of the stations in summer season are the highest level $(X=29.18$, $26.29,24.70)$. The Table 10 shows that the total amount of $\mathrm{Cr}, \mathrm{Ni}$ and $\mathrm{Cu}$ in the stations increased from spring to summer and from autumn to winter and decreased from winter to spring. In terms of $\mathrm{Cr}, \mathrm{Ni}$ and $\mathrm{Cu}$ levels in the stations, there is no statistically significant difference between spring and summer seasons $(\mathrm{p}>$.05). 
According to Table 10, obtained Kruskal Wallis H test results show that the amount of $\mathrm{Fe}$ in the stations is significantly difference in terms of seasons $(p<.01)$. The total Fe amount of the stations in the spring season is at the highest level compared to other seasons $(X=32.17)$. In spite of this, Fe amount of the stations is the lowest level in the autumn compared to other seasons $(X=14.70)$. In terms of spring and autumn seasons, the total amount of Fe in the stations showed statistically significant difference. This finding shows that the total amount of $\mathrm{Fe}$ in the stations decreased significantly from spring to summer and from summer to autumn, and increased from autumn to winter and spring.

Table 9. Kruskal Wallis $\mathrm{H}$ test results of $\mathrm{Cr}, \mathrm{Fe}, \mathrm{Ni}, \mathrm{Cu}$, $\mathrm{Pb}$ and $\mathrm{Al}$ values in the stations according to the control sample

\begin{tabular}{|c|c|c|c|c|c|c|c|}
\hline Metal & $G$ & $\mathrm{~N}$ & $X$ & $\mathrm{sd}$ & $x^{2}$ & $\mathrm{p}$ & dif. \\
\hline \multirow{5}{*}{$\mathrm{Cr}$} & G1 & 20 & 25.09 & \multirow{5}{*}{4} & \multirow{5}{*}{6.39} & \multirow{5}{*}{.17} & \multirow{5}{*}{-} \\
\hline & $\mathrm{G} 2$ & 11 & 25.50 & & & & \\
\hline & G3 & 10 & 34.38 & & & & \\
\hline & G4 & 4 & 27.25 & & & & \\
\hline & G5 & 1 & 18.48 & & & & \\
\hline \multirow{5}{*}{$\mathrm{Fe}$} & G1 & 20 & 24.45 & \multirow{5}{*}{4} & \multirow{5}{*}{.77} & \multirow{5}{*}{.94} & \multirow{5}{*}{-} \\
\hline & G2 & 11 & 24.18 & & & & \\
\hline & G3 & 10 & 20.60 & & & & \\
\hline & G4 & 4 & 25.25 & & & & \\
\hline & G5 & 1 & 19.00 & & & & \\
\hline \multirow{5}{*}{$\mathrm{Ni}$} & G1 & 20 & 21.73 & \multirow{5}{*}{4} & \multirow{5}{*}{3.00} & \multirow{5}{*}{.55} & \multirow{5}{*}{-} \\
\hline & $\mathrm{G} 2$ & 11 & 20.32 & & & & \\
\hline & G3 & 10 & 33.50 & & & & \\
\hline & G4 & 4 & 27.50 & & & & \\
\hline & G5 & 1 & 28.63 & & & & \\
\hline \multirow{5}{*}{$\mathrm{Cu}$} & G1 & 20 & 23.00 & \multirow{5}{*}{4} & \multirow{5}{*}{8.15} & \multirow{5}{*}{.08} & \multirow{5}{*}{-} \\
\hline & G2 & 11 & 22.55 & & & & \\
\hline & G3 & 10 & 28.38 & & & & \\
\hline & G4 & 4 & 8.38 & & & & \\
\hline & G5 & 1 & 20.90 & & & & \\
\hline \multirow{5}{*}{$\mathrm{Pb}$} & G1 & 20 & 24.60 & \multirow{5}{*}{4} & \multirow{5}{*}{2.17} & \multirow{5}{*}{.70} & \multirow{5}{*}{-} \\
\hline & G2 & 11 & 19.50 & & & & \\
\hline & G3 & 10 & 28.50 & & & & \\
\hline & G4 & 4 & 19.25 & & & & \\
\hline & G5 & 1 & 26.75 & & & & \\
\hline \multirow{5}{*}{$\mathrm{Al}$} & G1 & 20 & 27.05 & \multirow{5}{*}{4} & \multirow{5}{*}{2.87} & \multirow{5}{*}{.57} & \multirow{5}{*}{-} \\
\hline & $\mathrm{G} 2$ & 11 & 20.00 & & & & \\
\hline & G3 & 10 & 20.70 & & & & \\
\hline & G4 & 4 & 24.50 & & & & \\
\hline & G5 & 1 & 19.55 & & & & \\
\hline
\end{tabular}

p>. 05 ; 1 . Group: Crossroad-1, Crossroad-2, Crossroad3, Crossroad-4, Crossroad-5; 2. Group: Tevfik İleri Street -1, Tevfik İleri Street -2, Meydan Street; 3. Group: Sendika Street., Adliye Street.-1, Street-2; 4. Group: DVSTC; 5. Group: Control Sample (Scontrol); G: Group no, N: number of samples, X: mean ranks, sd: standard deviation, dif: difference

In Table 10, according to the results of Kruskal Wallis $\mathrm{H}$ test, the amount of $\mathrm{Pb}$ in stations shows a significant difference in terms of seasons $(\mathrm{p}<.01)$. The total $\mathrm{Pb}$ amount of the stations in the winter is highest compared to other seasons ( $\mathrm{X}=33.09)$. However, in the autumn season, the $\mathrm{Pb}$ amount of the stations is the lowest level in comparison to other seasons $(X=13.70)$. In terms of winter and autumn seasons, the total amount of $\mathrm{Pb}$ in the stations has a statistically significant difference. In addition, between the summer and winter seasons $\mathrm{Pb}$ amount is significantly different, also. These results indicate that the total $\mathrm{Pb}$ amount decreased from winter to autumn, from spring to summer and from summer to autumn and increased in winter season.

As Table 10 is examined, according to Kruskal Wallis $\mathrm{H}$ test results, $\mathrm{Al}$ level in stations shows a significant difference in terms of seasons $(p<.01)$. When compared to other seasons, the total amount of $\mathrm{Al}$ of the stations, is highest level in the spring ( $\mathrm{X}=33.25)$ and is the lowest level in summer season ( $X=14.75)$. In terms of spring and autumn seasons, the total amount of Al in the stations showed statistically significant differences. In addition, the amount of $\mathrm{Al}$ is significantly different between spring and summer seasons. The results in Table 10 indicate that the total amount of $\mathrm{Al}$ decreased from spring to summer and from summer to autumn and the total amount of $\mathrm{Al}$ in the stations increased from autumn to winter.

Table 10. Kruskal Wallis $\mathrm{H}$ test results of total $\mathrm{Cr}, \mathrm{Fe}$, $\mathrm{Ni}, \mathrm{Cu}, \mathrm{Pb}$ and $\mathrm{Al}$ values of the stations in terms of seasons

\begin{tabular}{|c|c|c|c|c|c|c|c|}
\hline Metal & $\mathrm{G}$ & $\mathrm{N}$ & $\mathrm{X}$ & sd & $\chi 2$ & $p$ & dif. \\
\hline \multirow{4}{*}{$\mathrm{Cr}$} & Summer & 12 & 29.18 & \multirow{4}{*}{3} & \multirow{4}{*}{5.79} & \multirow{4}{*}{.122} & \multirow{4}{*}{ - } \\
\hline & Autumn & 10 & 18.45 & & & & \\
\hline & Winter & 11 & 25.88 & & & & \\
\hline & Spring & 12 & 18.25 & & & & \\
\hline \multirow{4}{*}{$\mathrm{Fe}$} & Summer & 12 & 16.75 & \multirow{4}{*}{3} & \multirow{4}{*}{13.7} & \multirow{4}{*}{$\begin{array}{l}.003 \\
* *\end{array}$} & \multirow{4}{*}{$\begin{array}{l}1 S- \\
4 S, \\
2 S- \\
4 S\end{array}$} \\
\hline & Autumn & 10 & 14.70 & & & & \\
\hline & Winter & 11 & 27.36 & & & & \\
\hline & Spring & 12 & 32.17 & & & & \\
\hline \multirow{4}{*}{$\mathrm{Ni}$} & Summer & 12 & 26.29 & \multirow{4}{*}{3} & \multirow{4}{*}{1.06} & \multirow{4}{*}{.786} & \multirow{4}{*}{ - } \\
\hline & Autumn & 10 & 22.00 & & & & \\
\hline & Winter & 11 & 22.18 & & & & \\
\hline & Spring & 12 & 21.29 & & & & \\
\hline \multirow{4}{*}{$\mathrm{Cu}$} & Summer & 12 & 24.70 & \multirow{4}{*}{3} & \multirow{4}{*}{.67} & \multirow{4}{*}{.880} & \multirow{4}{*}{ - } \\
\hline & Autumn & 10 & 22.58 & & & & \\
\hline & Winter & 11 & 24.41 & & & & \\
\hline & Spring & 12 & 20.71 & & & & \\
\hline \multirow{4}{*}{$\mathrm{Pb}$} & Summer & 12 & 19.96 & \multirow{4}{*}{3} & \multirow{4}{*}{12.3} & \multirow{4}{*}{$\begin{array}{l}.006 \\
* *\end{array}$} & $2 S-$ \\
\hline & Autumn & 10 & 13.70 & & & & $3 S$, \\
\hline & Winter & 11 & 33.09 & & & & $1 \mathrm{~S}-$ \\
\hline & Spring & 12 & 24.54 & & & & $3 \mathrm{~S}$ \\
\hline \multirow{4}{*}{$\mathrm{Al}$} & Summer & 12 & 14.75 & \multirow{4}{*}{3} & \multirow{4}{*}{17.5} & \multirow{4}{*}{$\begin{array}{l}.001 \\
* *\end{array}$} & 1S- \\
\hline & Autumn & 10 & 14.90 & & & & $4 \mathrm{~S}$, \\
\hline & Winter & 11 & 28.18 & & & & $2 \mathrm{~S}-$ \\
\hline & Spring & 12 & 33.25 & & & & $4 \mathrm{~S}$ \\
\hline
\end{tabular}

$\mathrm{p}>.05,{ }^{* *} \mathrm{p}<.01,{ }^{* *} \mathrm{p}<.01,1 \mathrm{~S}$ :Summer, 2S: Autumn, 3S: Winter, 4S: Spring, N: number of samples, X: mean ranks, sd: standard deviation, dif: difference

\section{Conclusions}

In this study, $\mathrm{Cr}, \mathrm{Fe}, \mathrm{Ni}, \mathrm{Cu}, \mathrm{Pb}$ and $\mathrm{Al}$ concentration in the control sample were found as $8.4 \mu \mathrm{g} . \mathrm{g}-1,2185$

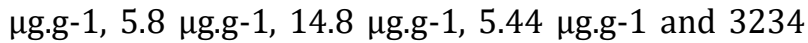
$\mu$ g.g- 1 , respectively. The average $\mathrm{Cr}, \mathrm{Fe}, \mathrm{Ni}, \mathrm{Cu}, \mathrm{Pb}$ and Al concentrations in the stations were found to be 9.5

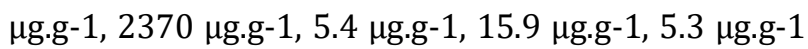
and $3712 \mu \mathrm{g} . \mathrm{g}-1$, respectively. The average $\mathrm{Cr}$, Fe and $\mathrm{Al}$ values in the stations are higher than the 
permissible values for plants. $\mathrm{Ni}, \mathrm{Cu}$ and $\mathrm{Pb}$ values are lower than permissible values for plants. Except Al, the detected average $\mathrm{Cr}, \mathrm{Fe}, \mathrm{Ni}, \mathrm{Cu}$ and $\mathrm{Pb}$ concentrations in stations are found lower than the average value obtained from some studies that determine the levels of heavy metal in moss samples in Turkey.

In this study, Kruskal Wallis $\mathrm{H}$ test was used to determine whether there was a significant difference for $\mathrm{Cr}, \mathrm{Fe}, \mathrm{Ni}, \mathrm{Cu}, \mathrm{Pb}$ and $\mathrm{Al}$ levels between the stations and the control sample. According to the test results it was no found statistically significant difference in terms of $\mathrm{Cr}, \mathrm{Fe}, \mathrm{Ni}, \mathrm{Cu}, \mathrm{Pb}$ and $\mathrm{Al}$ amounts between the stations and the control sample.

Kruskal Wallis $\mathrm{H}$ test was used to determine if there was a statistically significant difference in terms of total $\mathrm{Cr}, \mathrm{Fe}, \mathrm{Ni}, \mathrm{Cu}, \mathrm{Pb}$ and $\mathrm{Al}$ in the stations, also. According to the test results, it was determined that the total amount of $\mathrm{Cr}, \mathrm{Ni}$ and $\mathrm{Cu}$ in the stations in terms of seasons did not have a statistically significant difference even if they had different values.

The highest total amount of $\mathrm{Fe}$ and $\mathrm{Al}$ in the stations was found in the spring season and the highest total amount of $\mathrm{Pb}$ was found in the winter season. The lowest total amount of $\mathrm{Fe}$ and $\mathrm{Pb}$ in the stations was determined in autumn and the lowest total amount of $\mathrm{Al}$ was determined in summer season. The increased of total $\mathrm{Fe}$ and $\mathrm{Al}$ in the spring season and the increased of total $\mathrm{Pb}$ in the winter season, showed a statistically significant difference, according to the results of Kruskal Wallis H test.

The data obtained from this study is comparable with the data obtained from other studies. With the data of this study, a basic data were formed for the analyzes of the same or different stations in the following years. As a result of this data, it was concluded that Hypnum cupressiforme is a useful biomonitor organism that can be used in heavy metal accumulation and determination studies.

\section{Acknowledgment}

This study was supported by Recep Tayyip Erdogan University Scientific Research Projects Department under project no 2014.102.01.03.

\section{REFERENCES}

[1] Brown, D. H. 1984. Uptake of Mineral Elements and their Use in Pollution Monitoring. In: Dyer, A.F., Duckett, J.G. (Eds.), The Experimental Biology of Bryophytes. New York: Academic Pres.

[2] Nimis, P. L. 1996. Radiocesium Uptake and Cycling by Cryptogams in Natural Ecosystems. In: Giovani, C., Padovani, R., (Eds.), Atti 3-9 ANPA 1996, Conv. 10 Anni da Chernobyl, Roma.
[3] Bargagli, R., 1998. Trace Elements in Terrestrial Plants. An Ecophysiological Approach to Biomonitoring and Biorecovery. Berlin: Springer.

[4] Conti, M. E., Cecchetti, G. 2001. "Biological Monitoring: Lichens as Bioindicators of Air Pollution Assessment - A Review", Environmental Pollution, 114, 471-492.

[5] Goodman, G. T., Roberts, T.M. 1971. Plants and soils as indicators of metals in the air. Nature, Vol., 231, 287-292.

[6] IAEA-336Lichen, https://nucleus.iaea.org/rpst/referenceproduct s/referencematerials/Trace_Elements_Methylm ercury/IAEA-336.htm

[7] Uyar, G., Ören, M., Yildirim, Y., Ince, M.,. (2007). "Mosses as indicators of atmospheric heavy metal deposition around a coal-fired power plant in Turkey". Fresenius Environmental Bulletin. 16(2), 182-192.

[8] Uyar, G., Ören, M., Ince, M.,. (2007). “Atmospheric Heavy Metal Deposition in Düzce Province by Using Mosses as Biomonitors". Fresenius Environmental Bulletin. 16(2), 145-153.

[9] Uyar, G., Ören, M., Yıldırım, Y.,. (2008). "Biomonitoring of Metal Deposition in the Vicinity of Ereğli Steel Plant in Turkey". Environmental Forensics. 9:350-363.

[10] İçel, Y and Çobanoğlu G (2009) Biomonitoring of atmospheric heavy metal pollution using lichens and mosses in the city of Istanbul, Turkey. FEB 18: 2066-2071.

[11] Koz, B., Cevik, U., Bulut, V. N., Kaya, S., Gundogdu, A., \& Celik, N. (2013). Heavy Metal Analysis By Moss Species in the Black Sea Region of Turkey. Fresenius Environmental Bulletin, 22(4 B), 1287 1295.

[12] Yücel, D. 2010. Sakarya İli Sanayi Bölgesinin Yakın Cevresinde ve Șehir Merkezinde Oluşturduğu Atmosferik Ağır Metal Birikim Seviyelerinin Bir Biyomonitör Karayosunu (Hypnum cupressiforme Hedw.) ve Toprak Örnekleri Üzerinden Araştırılması, Yüksek Lisans Tezi, Zonguldak Karaelmas Üniversitesi, Fen Bilimleri Enstitüsü.

[13] Egili, E., Topcuoglu, S., Kut, D., Kırbasoglu, Ç., Esen, N., 2003. Heavy metals and radionuclides in lichens and mosses in Thrace, Turkey. Bull. Environ. Contam. Toxicol. 70, 502-508. 
[14] Uyar, G., Avcll, E, Örem, M., Karaca, F., Öncel, M.S., (2009). "Determination of Heavy Metal Pollution in Zonguldak (Turkey) by Moss Analysis (Hypnum cupressiforme). Environmental Engineering Science, 26 (1), 183-194.

[15] Belivermis, M., Kılıç, Ö., Çotuk, Y., 2008. Heavy Metal and Radioactivity concentrations in Soil and Moss samples from İstanbul, IUFS Journal of Biol. 67 (1), 39-47.

[16] World Health Organization, 2007. WHO Guidelines for Assessing Quality of Herbal Medicineswith Reference to Contaminants and Residues. Spain. 1-105.

[17] Deveci, T. 2012. Gaziantep'te Atık Sulardan Etkilenen Toprak ve Bitkilerde Eser Element $(\mathrm{Cu}$, $\mathrm{Co}, \mathrm{Mn}$ ve $\mathrm{Zn}$ ) ve Fe Konsantrasyonlarının ICP-MS ile Tayini. Kilis 7 Aralık Üniversitesi Fen Bilimleri Enstitüsü. Yüksek Lisans Tezi, 61s, Gaziantep.

[18] Khan, S. A., Khan, L., Hussain, I., Marwat, K. B., ve Akhtar, N. 2008. Profile of HeavyMetals in Selected Medicinal Plants. Pakistan Journal of Weed Science Research, 14 (1-2): 101-110.

[19] Tanak, A. G., 2006. Samsun Çevresinde Yetişen Bazı Yeșil Bitkilerdeki Ağır Metallerin Tayini. Yüksek Lisans Tezi, Ondokuz Mayıs Üniversitesi, Kimya Anabilim Dalı, Fen Bilimleri Enstitüsü, Samsun.

[20] Kartal, E.,2010. İstanbul Avrupa Yakası D-100 Karayolu Çevresindeki Bazı Bitkilerde Ağır Metal Birikimi, Yüksek Lisans Tezi, İstanbul Üniversitesi, Fen Bilimleri Enstitüsü, İstanbul.

[21] World Health Organization, 1999. WHO Monographs on Selected Medicinal Plants, Vol. I, Geneva, Switzerland. 1-295.

[22] Esetlili, B. Ç., Pekcan, T., Çobanoğlu, Ö., Aydoğdu, E., Turan, S., Anaç, D., 2014. Essential Plant Nutrients and Heavy Metals Concentrations of Some Medicinal and Aromatic Plants. Journal of Agricultural Sciences, 20: 239-247.

[23] Özcan, M., 2004. Mineral Contents of Some Plants Used as Condiments in Turkey, Food Chemistry, 84 (3): 437- 440. 